\title{
EFEKTIVITAS PEMEKARAN WILAYAH TERHADAP KINERJA PEGAWAI PEMERINTAH DALAM ERA OTONOMI DAERAH DI KOTA BATAM
}

\author{
Yustinus Farid Setyobudi \\ Program Studi Ilmu Pememrintahan Fakultas Ilmu Sosial dan Ilmu Politik Universitas Riau Kepulauan, \\ Indonesia \\ ayikbulbul@gmail.com
}

\begin{abstract}
Abstrak
Dengan dibukanya kran pemekaran wilayah sejak era reformasi, banyak daerah otonom baru yang sudah pisah dengan daerah induknya. Tercatat pada orde baru hanya 27 provinsi, hingga saat ini ada 34 provinsi. Sejak berlakunya Undang-Undang No 22 Tahun 1999 sebagai cikal bakal bagi daerah untuk memekarkan diri dari daerah induknya. Undang-Undang tersebut juga dianggap sebagai penguatan otonomi daerah dalam sistem pemerintahan di Indonesia, dulu yang sangat sentralistik tapi sekarang daerah diberi keleluasaan untuk mengurus rumah tangganya sendiri. Provinsi Kepulauan Riau, merupakan salah satu daerah yang memanfaatkan pemerkaran wilayah, khususnya Kota Batam. Provinsi Kepulauan Riau, sejak 2002 lepas secara administrasi dengan Provinsi Riau sebagai daerah induknya. Beberapa tahun yang lalu Kota Batam juga ada wacana untuk memekarkan wilayahnya, yang saat ini ada 12 Kecamatan, akan dimekarkan menjadi 16 kecamatan. Padahal dalam pelayanan publik, Kota Batam belum memerlukan daerah administrasi baru, yang dibutuhkan saat ini adalah corak Kota Batam itu sendiri. Selain itu masih banyak lagi permasalahan yang belum teratasi oleh pemerintah kota dalam memberikan pelayanan kepada masyarakat.
\end{abstract}

Kata Kunci: Efektivitas, Kinerja, Otonomi Daerah, Pemekaran.

\begin{abstract}
The journey of the government system, Indonesia experienced several phases. One of them is about regional autonomy. With the opening of the regional expansion valve since the reform era, many new autonomous regions have been separated from their parent regions. Recorded in the new order only 27 provinces, to date there are 34 provinces. Since the enactment of Law No. 22 of 1999 as a forerunner for the region to separate itself from its parent region. The law is also considered as strengthening regional autonomy in the government system in Indonesia, which was once very centralized but now the regions are given the freedom to take care of their own households. Riau Islands Province, is one of the areas that utilize regional extortion, especially Batam City. Riau Islands Province, since 2002 has been separated administratively by Riau Province as its parent region. Several years ago Batam City also had a discourse to expand its territory, which currently has 12 sub-districts, which will be divided into 16 sub-districts. Whereas in the public service, Batam City does not need a new administrative area, what is needed now is the style of Batam City itself. Besides that there are still many more problems that have not been resolved by the city government in providing services to the community.

Keywords: Efectivity, Regional Autonomy, Regional Segregation.
\end{abstract}




\section{PENDAHULUAN}

Sejak orde reformasi, pelaksanaan otonomi daerah diharapkan mampu menjadikan daerah lebih maju dan pelayanan pemerintah kepada masyarakat lebih efektif dan efisien. Pemerintah daerah diberikan hak dan kewenangan untuk mengatur urusan rumah tangganya sendiri, sehingga dapat mengurangi sentralistik yang ada di pemerintah pusat. Dengan adanya Undang-Undang No. 32 tahun 2004 yang saat ini diganti menjadi Undang-Undang 23 Tahun 2014 tentang Pemerintahan Daerah, semakin menunjukkan bahwa pemerintah pusat ingin menjadikan daerah sebagai ujung tombak sistem pemerintahan.

Selain pelimpahan kewenangan urusan pemerintahan dari pusat ke daerah yang diatur dalam UU 23 Tahun 20014, sebelumnya UU 22 Tahun 1999 yang merupakan cikal bakal terbukanya kran bagi daerah untuk melakukan pemekaran daerah. Pemekaran daerah dapat dilakukan pada semua tingkatan, baik tingkat propinsi, tingkat kabupaten/kota, maupun tingkat kecamatan. Pemekaran wilayah ini merupakan semangan untuk perbaikan pelayanan kepada masyarakat. Dengan harapan pelayanan kepada masyarakat lebih efisien dan efektif, karena administrasi pemerintah lebih terjangkau jaraknya oleh pemerintah dan tidak memakan waktu yang lama.

Berdasarkan data Kementerian Dalam Negeri, pemekaran daerah yang terjadi di Indonesia sejak orde reformasi ada 514 daerah otonom saat ini terdiri atas 416 kabupaten dan 98 kota yang tersebar di 34 Provinsi. Persyaratan pembentukan daerah telah diatur dalam PP No 129 Tahun 2000 tentang Persyaratan Pembentukan dan Kriteria Pemekaran, Penghapusan dan Penggabungan Daerah selanjutnya diganti dengan PP 78 Tahun 2007 tentang hal yang sama. Persyaratan yang diatur dalam kedua PP ini sebetulnya cukup ketat, tetapi dalam satu dasawarsa terakhir usulan pemekaran cenderung tidak terkendali.

Indonesia yang merupakan Negara kesatuan yang menganut asas desentralisasi dalam penyelenggaraan pemerintahan dengan memberikan kesempatan dan keleluasaan kepada pemerintah daerah untuk menyelenggarakan otonomi daerah. Sesuai amanat UU No. 23 tahun 2014 disebutkan bahwa otonomi daerah adalah hak, wewenang, dan kewajiban daerah otonom untuk mengatur dan mengurus sendiri urusan pemerintahan dan kepentingan masyarakat setempat sesuai dengan peraturan perundang-undangan. Dalam hal ini pemerintah daerah diarahkan untuk mempercepat terwujudnya kesejahteraan masyarakat melalui peningkatan, pelayanan, pemberdayaan, dan peran serta masyarakat, serta peningkatan daya 
saing daerah dengan memperhatikan prinsip demokrasi, pemerataan, keadilan, keistimewaan dan kekhususan suatu daerah dalam sistem Negara kesatuan Republik Indonesia.

Sejak tahun 1970-an, masyarakat Indonesia telah terintegrasi pada sistem ekonomi kapitalis dunia. Mulai dekade tersebut daerah-daerah di Indonesia berkembang pesat. Perkembangan tersebut lebih dapat diamati dalam konteks kota. Dalam hal ini pembangunan kota lebih diutamakan dan cenderung mengenyampingkan pedesaan. Tidaklah mengherankan apabila kesenjangan kota dan desa muncul, yang lebih dramatis lagi kota-kota berkembang secara tidak seimbang. Terdapat kota utama yang berkembang pesat, namun kota-kota lain bersifat periferal berkembang lambat.

Salah satu solusi untuk mengurangi kesenjangan antar daerah, kota, bahkan kawasan adalah otonomi daerah. Banyaknya perdebatan seputar otonomi daerah sebagai manifestasi dari desentralisasi kekuasaan pemerintah untuk bersungguh-sungguh dalam merealisasikan konsep otonomi daerah secara jujur, kerelaan dan konsekuen, guna terciptanya kesejahteraan bagi masyarakat. Semangat otonomi daerah sudah kelihatan dan menjadi dasar hukum pelaksanaan pemerintahan. Hanya saja semangat para penyelenggara pemerintahan masih jauh dari idealisme konsep otonomi daerah itu sendiri.

Menurut Bagir Manan dalam Marbun beliau menegaskan bahwa, sejarah ketatanegaraan Republik Indonesia sudah sejak semula meletakkan otonomi daerah sebagai salah satu sendi penting penyelenggaraan pemerintahan Negara. Otonomi daerah diadakan bukan sekedar menjamin efisiensi penyelenggaraan pemerintahan, bukan pula sekedar menampung kenyataan Negara yang luas, penduduk banyak, dan berpulau-pulau. Lebih dari itu, otonomi daerah merupakan dasar memperluas pelaksanaan demokrasi dan instrument mewujudkan kesejahteraan umum (Marbun, 2005).

Sebagai daerah otonom yang memiliki kewenangan untuk mengatur dan mengurus urusan pemerintahan dan kepentingan masyarakat setempat menurut prakarsa sendiri berdasarkan aspirasi masyarakat, setiap daerah memiliki kewenangan untuk menyusun Peraturan Daerah (Perda) sesuai dengan kebutuhan daerahnya, sesuai isi pasal 18 ayat (6) Undang-Undang Dasar Tahun 1945 yang disebutkan pemerintah daerah berhak menetapkan peraturan daerah dan peraturan-peraturan lain untuk melaksanakan otonomi dan tugas pembantuan. Otonomi yang melibatkan daerah-daerah diseluruh Indonesia diharapkan akan 
berdampak baik dalam menjalin hubungan kerjasama daerah di Indonesia, selain untuk memotivasi prestasi-prestasi pada daerahnya masing-masing.

Di era globalisasi saat ini diperlukan aparatur pemerintah yang bertugas sebagai abdi Negara dan abdi masyarakat harus mampu memberikan pelayanan prima yang dilakukan secara adil dan merata kepada masyarakat tanpa membedakan suku, ras, agama, jenis kelamin maupun tingkat sosialnya. Pelayanan prima merupakan suatu sikap atau cara aparatur pemerintah dalam melayani publik secara memuaskan, pelayan prima merupakan suatu pelayanan terbaik, melebihi, melampaui, mengungguli pelayanan yang diberikan pihak lain atau dari pada pelayanan waktu lampau.

Sebagai wujud dari tercapainya pelayanan prima diperlukan kinerja aparatur yang sesuai dengan tujuan instansi pemerintah. Bastian mendefinisikan kinerja sebagai prestasi yang dicapai oleh organisasi dalam periode tertentu (Sumarjo, 2000: 10).

\section{METODELOGI}

Pendekatan pada penelitian ini adalah kualitatif. Bogdan \& Taylor dalam Moleong (2007: 4) mendefinisikan metode kualitatif sebagai prosedur penelitian yang menghasilkan data deskriptif berupa katakata tertulis atau lisan dari orang-orang dan perilaku yang dapat diamati. Tempat penelitian di Kota Batam. Teknik pengumpulan data dengan studi dokumentasi. Analisis data dalam penelitian ini menggunakan Model Interaktif menurut Miles dan Hubberman dalam Sugiyono (2011: 224). Analisis model interaktif tersebut, terdiri dari pengumpulan data, reduksi data, penyajian data, dan penarikan kesimpulan.

\section{PEMBAHASAN}

\section{Efektivitas Kinerja Pegawai Pemerintah}

Hal pertama yang perlu menjadi kajian pertama adalah, bagaimana membebaskan birokrasi dari kekuasaan politik. Walaupun birokrasi resminya merupakan lembaga implementasi, tetapi sesungguhnya para aparatur sendiri memiliki diskresi yang tinggi dalam pembuatan-pembuatan kebijakan publik.

Hal demikian memungkinkan karena birokrasi dilengkapi sumber daya yang tidak dimiliki oleh lembaga-lembaga politik yang lain. Ia menguasai informasi yang diperlukan untuk pengambilan politik, ia bisa berkolaborasi dengan intelektual untuk merumuskan kebijakan secara teokratis, dan lain-lain (Darwin, 1996). 
Karenanya netralitas birokrasi merupakan konsep yang sangat penting. Netralitas yang dimaksud adalah birokrasi harus terlepas dari pengaruh politik birokrasi harus dikembalikan pada misi utamanya sebagai instrumen negara untuk melayani kepentingan publik ataupun memenuhi kebutuhan publik. Birokrasi model orde baru, dengan fungsi yang sangat banyak, seperti : sebagai instrumen pelayan publik, sebagai agen perubahan dan pembangunan, dan sebagai kekuatan pendukung utama Golkar, harus ditinggalkan.

Pada sisi lain, Muhajir Darwin mengemukakan, dua hal yang perlu dalam usaha netralisasi birokrasi : Pertama, institusi birokrasi dan risorsis yang ada di dalamnya tidak boleh dipakai sebagai alat untuk tujuan-tujuan politik penguasa. Partai politik tidak boleh menggunakan birokrasi untuk mencapai tujuan-tujuan politik mereka. Pegawai negeri sebagai individu merupakan warga negara yang bebas menggunakan hak-hak politiknya. Hak politik mereka bahkan tidak boleh di batasi, misalnya dengan prinsip monoloyalitas, tetapi para pegawai atau birokrat tidak boleh menggunakan kedudukan, jabatan dan dana publik yang dikuasai birokrasi untuk tujuan-tujuan politik birokrat tersebut. Kedua, politik pembinaan dari birokrasi harus dihapus. Birokrasi tidak bisa dan tidak boleh menjadi pembina politik. Hak politik warga negara untuk berkumpul dan berserikat serta menentukan pilihan-pilihan politik tidak perlu diarahkan atau dibatasi oleh birokrasi dengan dalih pembinaan.

Kehadiran partai politik dalam sistem birokrasi pemerintah tidak bisa dihindari di pusat maupun di daerah. Pemilihan langsung Presiden/Wapres yang merupakan wakil dari partai politik, dan kemudian diikuti dengan pemilihan Kepala Daerah mau tidak mau birokrasi pemerintah dipimpin oleh orang-orang politik.

Hadirnya orang politik dalam birokrasi pemerintah membawa konsekuensi ada jabatan politik dan ada pula jabatan karier. Sementara itu dalam birokrasi pemerintah belum ada batasan yang jelas antara kedua jabatan tersebut. Pejabat politik yang mengisi birokrasi pemerintah sangat dominan. Kondisi ini cukup lama terbangun sehingga membentuk sikap, perilaku, dan opini bahwa pejabat politik dan pejabat karir tidak dapat dibedakan. Kewenangan besar dimiliki birokrat sehingga hampir semua aspek kehidupan masyarakat ditangani birokrasi. Kewenangan yang terlalu besar itu bahkan akhirnya menonjolkan peran birokrasi sebagai pembuat kebijakan ketimbang pelaksana kebijakan, lebih bersifat menguasai daripada melayani masyarakat. Akhirnya, birokrasi lebih dianggap sebagai 
sumber masalah atau beban masyarakat ketimbang sumber solusi bagi masalah yang dihadapi masyarakat.

Susunan birokrasi pemerintah bukan hanya diisi oleh para birokrat karier tertapi juga pejabat politik. Menurut teori liberal, birokrasi pemerintah menjalankan kebijakan-kebijakan pemerintah yang mempunyai akses langsung dengan rakyat melalui mandat yang diperoleh dalam pemilihan umum. Dengan demikian birokrasi pemerintah itu bukan hanya diisi oleh para birokrat, melainkan ada bagian-bagian tertentu yang diduduki oleh pejabat politik. Demikian pula sebaliknya bahwa di dalam birokrasi pemerintah itu bukan hanya dimiliki oleh pemimpin politik dari partai politik tertentu saja melainkan ada juga pemimpin birokrasi karier professional. Permasalahan sekarang yaitu banyak terjadi anomali-anomali seperti yang disebut diatas, bahwa yang seharusnya menyeleksi panglima TNI adalah orang-orang dikalangan TNI itu sendiri karena jabatan panglima TNI merupakan jabatan karir. Tetapi kenapa jabatan karir yang menyeleksi orang-orang politik yang dalam hal ini anggota dewan sebagai pemegang jabatan politik selain presiden, menteri, kepala daerah. Ini merupakan hal yang perlu diperhatikan bahwa harus ada kejelasan batas antara kedua jabatan tersebut.

Ketika keinginan memasukkan pejabat politik dalam birokrasi pemerintah itu timbul, maka timbul pula suatu pertanyaan tentang hubungan keduanya. Pertanyaan ini harus dijernihkan dengan jawaban yang tepat. Hubungan antara pejabat politik (political leadership) dan birokrasi merupakan suatu hubungan yang konstan (tetap) antara fungsi kontrol dan dominasi. Dalam hubungan seperti ini, maka akan senantiasa timbul persoalan, siapa mengontrol siapa dan siapa pula yang menguasai, memimpin dan mendominasi siapa.

Persoalan ini sebenarnya merupakan persoalan klasik sebagai perwujudan dikotomi politik dan administrasi. Sehingga kemudian timbul dua bentuk alternatif solusi yang ditawarkan Carino, yakni apakah birokrasi sebagai subordinasi dari politik (executive ascendancy) atau birokrasi sejajar dengan politik (bureaucratic sublation). Bentuk solusi executive ascendancy diturunkan dari suatu anggapan bahwa kepemimpinan pejabat politik itu didasarkan atas kepercayaannya bahwa supremasi mandat yang diperoleh oleh kepemimpinan politik itu didasarkan atas kepercayaan bahwa supremasi mandat yang diperoleh oleh kepemimpinan politik itu berasal dari Tuhan atau berasal dari rakyat atau berasal dari public interst. Supremasi mandat ini dilegitimasikan melalui pemilihan, atau kekerasan, atau penerimaan secara de facto oleh rakyat. Sedangkan bentuk bureaucratic 
sublation didasarkan atas anggapan bahwa birokrasi pemerintah suatu negara itu bukanlah hanya berfungsi sebagai mesin pelaksana. Max Weber sendiri mengenalkan bahwa birokrasi yang riil mempunyai kekuasaan yang terpisah dari kekuasaan yang dilimpahkan oleh pejabat politik. Pejabat karir yang terlatih secara profesional mempunyai kekuatan tersendiri sebagai pejabat yang permanen, maka pejabat karir itu mempunyai kekuatan yang seimbang dengan pejabat politik. Oleh karena itu, kedudukannya tidak sekedar sebagai subordinasi dan mesin pelaksana melainkan sebanding, birokrasi bukan merupakan partisipan politik akan tetapi karena keahliannya mempunyai kekuatan untuk membuat kebijakan yang profesional (Thoha, 2003).

Dalam melihat efektivitas pegawai, menurut pendapat Richard Steers dalam Bonita (2018), menambahkan ada empat faktor yang mempengaruhi efektivitas :

1. Karakteristik Organisasi adalah hubungan yang sifatnya relatif tetap seperti susunan sumber daya manusia yang terdapat dalam organisasi. Struktur merupakan cara yang unik menempatkan manusia dalam rangka menciptakan sebuah organisasi. Dalam struktur, manusia ditempatkan sebagai bagian dari suatu hubungan yang relatif tetap yang akan menentukan pola interaksi dan tingkah laku yang berorientasi pada tugas.

2. Karakteristik Lingkungan, mencakup dua aspek. Aspek pertama adalah lingkungan ekstern yaitu lingkungan yang berada di luar batas organisasi dan sangat berpengaruh terhadap organisasi, terutama dalam pembuatan keputusan dan pengambilan tindakan. Aspek kedua adalah lingkungan intern yang dikenal sebagai iklim organisasi yaitu lingkungan yang secara keseluruhan dalam lingkungan organisasi dalam menjalankan fungsinya.

3. Karakteristik Pekerja merupakan faktor yang paling berpengaruh terhadap efektivitas. Di dalam diri setiap individu akan ditemukan banyak perbedaan, akan tetapi kesadaran individu akan perbedaan itu sangat penting dalam upaya mencapai tujuan organisasi. Jadi apabila suatu organisasi menginginkan keberhasilan, organisasi tersebut harus dapat mengintegrasikan tujuan individu dengan tujuan organisasi. Untuk itu diperlukan adanya etos kerja untuk setiap pegawai (individu).

4. Karakteristik Manajemen adalah strategi dan mekanisme kerja yang dirancang untuk mengkondisikan semua hal yang di dalam organisasi sehingga efektivitas tercapai. Kebijakan dan praktek manajemen merupakan alat bagi pimpinan untuk mengarahkan 
setiap kegiatan guna mencapai tujuan organisasi. Dalam melaksanakan kebijakan dan praktek manajemen harus memperhatikan manusia, tidak hanya mementingkan strategi dan mekanisme kerja saja. Mekanisme ini meliputi penyusunan tujuan strategis, pencarian dan pemanfaatan atas sumber daya, penciptaan lingkungan prestasi, proses komunikasi, kepemimpinan dan pengambilan keputusan, serta adaptasi terhadap perubahan lingkungan inovasi organisasi.

Dari penjelasan tersebut diatas, untuk mengukur efektivitas kinerja pegawai dapat dilihat dari empat faktor yang telah dijelaskan diatas. Dengan penjelasan itu bahwa seorang pegawai pemerintah perlu memahami dalam mejalankan tugasnya harus tahu bagaimana karakteristik organisasinya, karakteristik lingkungannya, karakteristik pekerja, dan karakteristik manajemennya.

Dalam menjalankan tugasnya, pegawai pemerintah lebih takut kepada atasannya. Padahal pegawai pemerintah seharusnya harus takut kepada rakyat yang mempercayainya, karena mereka digaji oleh masyarakat sebagai pelayan masyarakat. Kegiatan birokrasi tidak lagi cocok dengan kegiatan rakyat, maka birokrasi harus mau mempertanggung-jawabkan kepada rakyat dengan cara akuntabilitas kinerja kepada khalayak umum. Jika akuntabilitas ini benar-benar dikerjakan oleh birokrasi, maka transparansi, keterbukaan, dan kejujuran akan diperlihatkan oleh kinerja birokrasi.

Dengan pandangan masyarakat seperti itu, maka pegawai pemerintah dianggap hanya menghabiskan dana dari kas negara dan kegiatan mereka hanyalah memainkan kertas saja. Masih banyak didapati kasus terkait dengan kinerja pegawai di kantor, antara lain yang datang ke kantor hanya untuk baca koran, main catur dengan rekan kerja seruangan, bahkan tidak jarang yang main game komputer di kantor. Fenomena ini sering dijumpai dilapangan dan sudah menjadi hal yang biasa, padahal tugas masih banyak yang terbengkalai.

\section{BATAM DITENGAH PEMEKARAN WILAYAH}

Dengan adanya rencana pemekaran wilayah di Batam, yaitu dengan pemekaran Kecamatan yang dulu hanya 12 akan menjadi 16 atau 21 Kecamatan menimbulkan berbagai reaksi di masyarakat, khususnya di kalangan akademisi. Secara menyeluruh ini merupakan kemajuan bagi Batam sebagai daerah yang baru berkembang, namun disisi lain akan menjadikan tanda tanya besar bagi Pemerintah Kota Batam. Tanda tanya itu adalah sanggup 
tidak dalam pemekaran ini baik secara finansial maupun administrasi ditanggung oleh Pemerintah Kota Batam dengan APBDnya. Jangan sampai dengan pemekaran yang rencana awalnya adalah untuk lebih mengefektifkan pelayanan kepada masyarakat, bisa berubah menjadi beban bagi Pemerintah Kota Batam dibelakang besok.

Melihat kondisi Batam saat ini memang membutuhkan pelayanan yang cepat kepada masyarakat, belum lagi predikat yang disandang bahwa Batam salah satu daerah dengan pembangun peradaban manusia. Artinya Batam memiliki daya tarik bagi masyarakat dari luar Batam untuk mengadu nasib di "Pulau Kalajengking" ini. Jika penduduk Batam semakin bertambah maka secara tidak langsung pelayanan yang akan dituntut masyarakat akan bertambah dalam kuantitasnya. Misalnya di kecamatan yang biasanya hanya melayani 100 orang dalam pengurusan dokumen/perizinan dalam berbagai bentuk, maka bisa jadi akan bertambah 2 kali lipat jumlah orang dalam per harinya jika penduduk di Batam semakin bertambah.

Namun semua itu seharusnya menjadi perhatian bagi Pemerintah Kota Batam, bahwa yang dibutuhkan Batam saat ini bukan pemekaran wilayah. Sampai detik ini, dengan 12 Kecamatan saja secara keseluruhan ternyata birokrasi pemerintah masih bisa memberikan pelayanan masyarakat dengan baik. Seharusnya yang menjadi perhatian Pemerintah Kota adalah pelayanan yang diberikan dalam dunia pendidikan. Sebagai contoh masih banyak siswa yang tinggal di pulau-pulau yang berada diluar daratan Batam yang harus berangkat ke sekolah harus dengan melepas sepatunya, kemudian setelah menyebrang dari pulau tempat dia tinggal dan sampai di daratan, baru mereka memakai sepatunya karena takut basah atau kotor, serta tak jarang dari mereka menggunakan sepatunya di depan sekolah. Hal ini menunjukkan bahwa pemerintah kota masih belum fokus terhadap apa yang menjadi prioritas dalam pemngembangan Batam kedepannya. Untuk akses menuju sekolah saja, para pelajar harus berjuang ekstra agar bisa sampai disekolah. Yang lebih memprihatinkan lagi adalah sarana angkutan umum untuk para pelajar, di wilayah Barelang dan Punggur misalnya, masih banyak siswa yang harus berjalan kaki untuk menuju ke sekolah, tidak jarang mereka mencari tumpangan mobil pribadi untuk bisa sampai disekolah karena minimnya angkutan umum. Hal itu tidak akan terjadi apabila di daerah Barelang dan Punggur diberi fasilitas angkutan yang khusus untuk pelajar dan tanpa memungut biaya (gratis). 
Saat ini seharusnya Pemerintah Kota Batam sudah mulai memetakan mana yang menjadi prioritas dalam pembangunan untuk Batam kedepannya. Batam mau menjadi Kota Pariwisata, atau Batam mau menjadi Kota Pendidikan, maupun Batam mau menjadi Kota Industri, dan atau Batam mau menjadi Kota Budaya Melayu, sehingga Batam akan memiliki kekhasan atau nilai lebih seperti daerah-daerah lain di Indonesia, misalnya Malang Kota Apel, Jogja Kota Gudeg, Pekalongan Kota Batik, dan sebagainya.

\section{KESIMPULAN}

Dari penjelasan diatas, maka dalam efektivitas pemekaran wilayah terhadap kinerja pegawai pemerintah di Kota Batam dalam era otonomi daerah, dapat ditarik kesimpulan bahwa sejak reformasi daerah diberi peluang untuk memekarkan wilayahnya. Di beberapa daerah pemekarah, memang menimbulkan masalah, karena ada daerah yang belum siap baik secara sumber daya dan pengelolaannya, sehingga masih bergantung pada daerah induknya. Pemekaran wilayah pada awalnya memiliki semangat untuk perbaikan pelayanan publik yang pada orde baru terkenal dengan berbelit-belit, kaku, dan membutuhkan waktu yang lama dalam prosesnya. Dengan semangat tersebut tidak diimbangi dengan kesiapan sumber daya manusia di daerah pemekaran. Hal ini menyebabkan kinerja pegawai kurang efektif, sehingga banyak daerah pemekaran masih bingung untuk menentukan keunggulan atau kekhasan daerahnya, seperti halnya Kota Batam yang belum terlihat kekhasannya. Padahal untuk mengukur efektivitas kinerja pegawai dapat diukur dari karakteristik organisasi, karakteristik lingkungan, karakteristik pekerja, karakteristik manajemen. 


\section{DAFTAR PUSTAKA}

Darwin, Muhadjir. (1996). Demokratisasi Birokrasi di Indonesia, Dalam Demokrasi Kontemporer, Editor Riza Noer Irfani. Jakarta: PT Raja Grafindo Persada.

Dwiyanto, Agus Dkk, Reformasi Birokrasi Publik di Indonesia, 2002, Yogyakarta : Gadjah Mada University Press.

Marbun, B.N. (2005). Otonomi Daerah 1945-2005 Proses dan Realita perkembangan Otda Sejak Zaman Kolonial Sampai Saat ini. Jakarta : Pustaka Sinar Harapan.

Moleong, L.J. (2007). Metodologi Penelitian Kualitatif. Bandung: PT. Remaja Rosdakarya.

Moningka, Shinta Bonita. (2018). Efektivitas Kerja Pegawai Negeri Sipil Dalam Pelayanan Publik Di Kantor Kelurahan Kolongan Kecamatan Tomohon Tengah Kota Tomohon. Diunduh dari https://ejournal.unsrat.ac.id/index.php/politico/article/view/5175 pada 28 September 2018.

Sugiyono. (2011). Metode Penelitian Kuantitatif Kualitatif dan $R \& D$. Bandung: Alfabeta.

Sumarjo, Hendro. (2000). Pengaruh Karakteristik Pemerintah Daerah Terhadap Kinerja Keuangan Pemerintah Daerah. Surakarta : USM.

Thoha, Miftah. (2003) Birokrasi dan Politik di Indonesia, Jakarta : Raja Grafindo Persada.

Undang-Undang Nomor 22 Tahun 1999

Undang-Undang Nomor 32 Tahun 2004

Undang-Undang Nomor 23 Tahun 2014

Peraturan Pemerintah Nomor 78 Tahun 2007 